\title{
Związek między Baconem, teleologią $i$ analogią a doktryną naturalizmu metodologicznego *
}

Francis Bacon podzielił nauki przyrodnicze na fizykę i metafizykę. Twierdził, że z czterech przyczyn wskazanych przez Arystotelesa tylko przyczyny materialne i sprawcze należą do dziedziny fizyki, a przyczyny celowe, czy też twierdzenia teleologiczne, zaliczyć trzeba do dziedziny metafizyki. Bacon sprzeciwiał się włączaniu teleologii do fizyki, ponieważ doświadczenie podpowiadało mu, że twierdzenia teleologiczne zniechęcają do poszukiwania przyczyn sprawczych dla zjawisk przyrodniczych. Relegował on teleologię do metafizyki, a nauka w dużej mierze poszła jego śladem, wykształcając przez kolejne czterysta lat coraz większą awersję do uwzględniania czynników teleologicznych w wyjaśnieniach naukowych. Zdaniem Bacona człowiek, z racji swojej natury, „wymyśla [...] paralele, odpowiedniości i stosunki, które w rzeczywistości nie istnieją".

Jednak wraz $\mathrm{z}$ rozwojem nauki w zakresie odkrywania przyczyn materialnych i sprawczych, jaki zachodził od czasów Bacona, zaczęły pojawiać się paralele, odpowiedniości i stosunki bardziej zasadne niż zapewne mógłby on sobie

James C. LeMAster, Ph.D. — Houston Baptist University, e-mail: jclemaster4@gmail.com.

(C) Copyright by James C. LeMaster, Blyth Institute Press, Dariusz Sagan \& Filozoficzne Aspekty Genezy.

* James C. LeMaster, ,The Relationship of Bacon, Teleology, and Analogy to the Doctrine of Methodological Naturalism”, w: Jonathan BartLetT and Eric Holloway (eds.), Naturalism and Its Alternatives in Scientific Methodologies: Proceedings of the 2016 Conference on Alternatives to Methodological Naturalism, Blyth Institute Press, Broken Arrow, Oklahoma 2017, s. 67-89. Za zgodą Autora i Wydawnictwa z języka angielskiego przełożył: Dariusz SAGAN. 
wyobrazić. Krótko mówiąc, poszukiwanie przyczyn materialnych i sprawczych w przyrodzie przyniosło imponujące uzasadnienie również dla wnioskowania o przyczynach celowych. Wnioskowania teleologiczne powinny być dopuszczone w nauce wówczas, gdy uprawomocniają je świadectwa empiryczne.

Narzędzie pozwalające ustalić, czy wnioskowanie teleologiczne jest prawomocne, stanowi analogia. Bacon mógłby pomóc nauce uniknąc stopniowego, lecz i nieuchronnego przejścia w stronę naturalizmu metodologicznego, gdyby położył nacisk na to, jak analogia, zastosowana w roli narzędzia analitycznego w procesie indukcji, prowadzi do zasadnych wniosków o istnieniu teleologii w przyrodzie.

\section{Bacon jako pionier naturalizmu metodologicznego}

Niektórzy uczeni twierdzą, że nowożytne korzenie naturalizmu metodologicznego sięgają - przynajmniej częściowo - poglądu Francisa Bacona na przyczyny celowe. Michael Ruse komentuje, że Bacon, ,,angielski filozof teorii i metodologii naukowej [...] nie chciał zaprzeczać, że Bóg stoi za swoim projektem, ale [...] zależało mu na utrzymaniu tego sposobu myślenia poza nauką". ${ }^{1}$ Omawiając genezę rewolucji naukowej w siedemnastym wieku, Harry Lee Poe i Chelsea Rose Mytyk piszą, że duże zmiany przyniosła „dopiero zaproponowana przez Bacona nowa, rygorystyczna metoda badań fizycznego świata”. Nowa metoda Bacona, dodają, obejmowała też wyraźne rozróżnienie dwóch ogólnych kategorii przyczynowych: „Metafizyka mówi o przyczynach celowych lub ostatecznych, natomiast obserwacje świata wskazują na bezpośrednie przyczyny w sferze empirii". ${ }^{2}$ Cornelius Hunter uważa, że chociaż Bacon pragnął, by nauka poszukiwała prawdziwych wyjaśnień świata, to „chciał też, by [...] ograniczała się [ona] do wyjaśnień naturalistycznych. Bacon wiedział, że ograniczenie

\footnotetext{
${ }^{1}$ Michael Ruse, „The Argument From Design: A Brief History”, w: William A. Dembski and Michael Ruse (eds.), Debating Design: From Darwin to DNA, Cambridge University Press, Cambridge 2004, s. 16 [13-31].

${ }^{2}$ Harry Lee Poe i Chelsea Rose Мүтүк, „Od metody naukowej do naturalizmu metodologicznego. Ewolucja idei”, przeł. Bartosz Błaszczak, Gerard Dmuch, Ewa Komorowska, Iwona Kumiszcze, Izabela Obłaczyńska, Katarzyna Piłka, Radosław Plato, Marika Poprawska, Dariusz Sagan, Karolina Stencel, Katarzyna Szot i Piotr Wróblewski, Filozoficzne Aspekty Genezy 2011, t. 8 , s. 142-143 [137-151], http://www.nauka-a-religia.uz.zgora.pl/images/FAG/2011.t.8/art.09.pdf (30. 11.2017).
} 
do naturalizmu wykluczy wszystkie realistyczne, prawdziwe wyjaśnienia, które nie są ściśle naturalistyczne. [...] Tak więc Bacon [...] zrezygnował z zupełności”. W myśl jego nowego paradygmatu „nauka nie badałaby wszystkich rzeczy". ${ }^{3}$

Bacon całkiem wyraźnie wskazał swój cel wykluczenia przyczyn celowych — lub wyjaśnień teleologicznych — z dziedziny fizyki i zaliczenia ich do metafizyki:

Fizyka zajmuje się tym, co najbardziej przyrodzone materii, a więc i przemijające, metafizyka zaś tym, co bardziej abstrakcyjne i trwałe. Fizyka widzi w przyrodzie tylko byt, ruch i naturalną konieczność, natomiast metafizyka widzi również umysł i ideę. [...] Prawdziwa różnica między nimi musi mieć źródło w naturze badanych przez nie przyczyn. [...] Fizyka bada i zajmuje się przyczynami materialnymi i sprawczymi, metafizyka - formalnymi i celowymi. ${ }^{4}$

Jakie Bacon miał powody, by ograniczać wnioskowania lub wyjaśnienia teleologiczne do dziedziny metafizyki i wykluczać je z bardziej praktycznej dziedziny eksperymentalnej, empirycznej i indukcyjnej fizyki?

\section{Bacon i relegacja teleologii do metafizyki}

Bacon, przyglądając się historii, uświadamiał sobie i ubolewał nad tym, że przez wiele wieków badacze przyrody często bezkrytycznie ulegali skłonności do przywoływania przyczyn celowych. Tendencja ta, podkreślał Bacon, ,jest dla nauk raczej szkodliwa i na nic się nie przydaje". ${ }^{5}$

\footnotetext{
${ }^{3}$ Cornelius HunTer, „What Evolutionists Don't Understand About Methodological Naturalism", Darwin's God 27 April 2012, http://darwins-god.blogspot.com/2012/04/what-evolutionistsdont-understand.html (30.11.2017).

${ }^{4}$ Francis BACON, De dignitate et augmentis scientiarum, w: John M. ROBERTSON (ed.), The Philosophical Works of Francis Bacon, George Routledge and Sons, London 1905, s. 459 [413638].

${ }^{5}$ Franciszek BACON, Novum Organum, przeł. Jan Wikarjak, Biblioteka Klasyków Filozofii, Państwowe Wydawnictwo Naukowe, Warszawa 1955, 2:2, s. 163.
} 


\subsection{Idole teatru}

Jednym z czynników, na jakie Bacon zrzucił dużą część winy za to szkodliwe oddziaływanie, były długotrwałe skutki poglądów słynnych starożytnych Greków na filozofię przyrody. Bacon, wyrzekając się starożytnej tendencji do wznoszenia tego, co nazwał ,idolami teatru”, potępił różnych starożytnych myślicieli greckich za brak dbałości o pilne, gruntowne, empiryczne eksperymenty i obserwacje, a także za zbyt pośpieszne i zbyt częste kierowanie się sofisterią i przesądami w interpretacji przyrody. ,[Arystoteles] już uprzednio rozstrzygną sprawę”, zarzucał Bacon, ,i przy ustalaniu praw i twierdzeń wcale nie radził się, jak należy, doświadczenia, lecz rozstrzygnąwszy kwestię według swego widzi mi się, naginał potem doświadczenie do swego poglądu i oprowadzał je niby jeńca”. ${ }^{6}$ Bacon następnie rozszerzył swoją krytykę: „,Wojowniczy bowiem sofistyczny kierunek filozofii usidla rozum, lecz ten drugi kierunek, fantastyczny, napuszony i jakby poetycki, bardziej schlebia rozumowi. [...] Jeśli chodzi o Greków, osobliwy przykład tego rodzaju stanowi Pitagoras [...] natomiast w sposób bardziej niebezpieczny i subtelny [widoczny jest] u Platona i jego szkoły”. ${ }^{7}$ Bacon narzekał, że „Tego rodzaju zło znajduje się częściowo także w pozostałych systemach filozoficznych, kiedy wprowadzają one abstrakcyjne formy, przyczyny celowe, pierwsze przyczyny, a pomijają najczęściej przyczyny pośrednie itd." 8

Bacon szczególnie silnie odrzucał to, w czym widział niegdysiejszą (czy to u starożytnych greckich filozofów przyrody, czy u ich późniejszych chrześcijańskich odpowiedników) skłonność do zbyt pośpiesznego przeskakiwania od zbyt skąpych danych eksperymentalnych do uniwersalnych zasad, a następnie do dedukcyjnego wyprowadzania twierdzeń na temat przyrody z tych filozoficznych uogólnień:

Jaka bowiem była u starożytnych forma poszukiwania i odkrywania, to i oni sami wyraźnie mówią, i ich pisma pokazują. A polegała ona na tym, że od kilku przykładów i szczegółów [...] wzlatywali od razu do wniosków najbardziej ogólnych czy do naczelnych zasad nauk i opierając się na ich niewzruszonej i ustalonej prawdziwości, wy-

\footnotetext{
${ }^{6}$ Bacon, Novum Organum..., 1:63, s. 83.

${ }^{7}$ BACON, Novum Organum..., 1:65, s. 84-85.

${ }^{8}$ Bacon, Novum Organum..., $1: 65$, s. 85.
} 
prowadzali i uzasadniali przy pomocy średnich niższe wnioski $[\ldots]$ a to wzlatywanie do tego, co najbardziej ogólne, zgubiło wszystko. ${ }^{9}$

Bacon beształ także tych spośród jego współczesnych (na przykład alchemików), którzy podążali za złym przykładem wpływowych Greków. Oni również popadali w błąd ,z powodu przedwczesnego i zbyt skwapliwego pośpiechu rozumu, z powodu przeskoków, a raczej ulatania od razu do tego, co najogólniejsze i do naczelnych zasad". ${ }^{10}$ Za godny pożałowania stan filozofii przyrody Bacon winił więc nie tylko starożytnych myślicieli greckich, ale też stanowczo krytykował część filozofów przyrody, którzy pojawili po epokach greckiej i chrześcijańskiej:

Zepsucie filozofii spowodowane przesądami i domieszką teologii zatacza najszersze kręgi i przynosi najwięcej zła [...]. A niektórzy z nowożytnych z największą lekkomyślnością do tego stopnia oddawali się tym urojeniom, że usiłowali oprzeć filozofię naturalną na pierwszym rozdziale Genesis, na Księdze Joba i innych świętych pismach. ${ }^{11}$

Przeprowadzona przez Bacona krytyka przeszłych i współczesnych mu chrześcijańskich filozofów przyrody zdaje się sugerować, że zbyt łatwo ulegali oni wpływowi swych starożytnych, greckich poprzedników. Tak więc, być może $\mathrm{z}$ jego punktu widzenia, największa wina i tak leżała po stronie Greków.

\subsection{Idole plemienia}

Winą za tak dhugotrwałe zacofanie filozofii przyrody Bacon obarczał też inne idole - „idole plemienia”, jak je nazwał. Do tej kategorii zaliczał to, co uważał za poważne uprzedzenia oraz błędy percepcji i rozumowania, którymi ludzie są w sposób naturalny i powszechny skażeni. Poza tym, że według Bacona wywodzą się one z wpływu starożytnych myślicieli greckich, twierdził on, że potępiana przez niego pochopna, nazbyt dedukcyjna metoda bierze się ,z przyrodzonej skłonności rozumu”. ${ }^{12}$ Baconowi chodziło konkretnie o to, że „począ-

\footnotetext{
${ }^{9}$ BACON, Novum Organum..., 1:125, s. 154-155.

${ }^{10}$ BACon, Novum Organum..., 1:64, s. 84.

${ }^{11}$ BACON, Novum Organum..., 1:65, s. 84-85.

${ }^{12}$ BACON, Novum Organum..., 1:104, s. 132.
} 
tek [...] biorą one [idole plemienia] albo z jednorodności substancji ducha ludzkiego, albo z jego uprzedzeń, albo z jego ograniczoności, albo z nieustannej jego ruchliwości, albo z wpływu uczuć, albo z nieudolności zmysłów, albo z tego, co nań robi wrażenie". ${ }^{13}$

Najwyraźniej Bacon dostrzegał wiele poważnych uchybień w przyrodzonych ludziom zdolnościach percepcyjnych i rozumowych. Jedno z nich zasługuje jednak na szczególną uwagę ze względu na cele niniejszego artykułu. Uchybieniem tym, według Bacona, jest tendencja do błędnego dostrzegania zbyt wielkich celowych podobieństw, wzorców i prawidłowości w przyrodzie niż rzeczywiście istnieją. Utrzymywał on, że „Rozum ludzki ma tę właściwość, że skłonny jest przyjmować większy porządek i większą prawidłowość w świecie niż naprawdę znajduje". ${ }^{14}$

Możliwe też, że Bacon czuł, iż ludzie mają skłonność do błędnego identyfikowania mechanicznych oddziaływań w przyrodzie. Pisał: „Umysł ludzki do tego stopnia przejmuje się widokiem tego, co dzieje się w sztukach mechanicznych, w których ciała w drodze połączeń i rozłączeń ulegają bardzo różnorodnym zmianom, iż sądzi się, że coś podobnego dzieje się także w ogólnej naturze rzeczy". ${ }^{15}$ Być może stawiał on zarzut, że jesteśmy tak dobrze obeznani z urządzeniami mechanicznymi — oraz z czynnikami teleologicznymi odpowiadającymi za ich powstanie - że podobną mechaniczną teleologię błędnie przypisujemy złożonym zjawiskom, organizmom lub strukturom, które obserwujemy w przyrodzie. Innymi słowy, upieramy się, że między zjawiskami przyrodniczymi a wytworzonymi przez człowieka artefaktami zachodzi analogia, ale nie ma to uzasadnienia. ${ }^{16}$

W różnych fragmentach pism Bacona można odnaleźć inną możliwą wskazówkę, dlaczego żywił on tak pesymistyczny pogląd na wiarygodność ludzkiego rozumowania, włączając $\mathrm{w}$ to pojmowanie przyrody przez człowieka. Jak się wydaje, przyjmował on jako coś niekwestionowalnego, że między ludzkimi a boskimi metodami, schematami i zdolnościami myślenia istnieje ogromna, być

\footnotetext{
${ }^{13}$ BACON, Novum Organum..., 1:52, s. 74.

${ }^{14}$ BACON, Novum Organum..., 1:45, s. 69.

${ }^{15}$ B ACon, Novum Organum..., 1:66, s. 85-86.

${ }^{16}$ Później David Hume w podobny sposób skrytykował tezę o istnieniu analogii między zja wiskami przyrodniczymi a artefaktami. Odniosę się do tej krytyki w dalszej części artykułu.
} 
może nawet absolutna, przepaść. Mówił on, że obrońcy „religii chrześcijańskiej [...] wysławiali [...] uroczyście i z wielką okazałością ten związek wiary i zmysłów jako prawowity [...] tymczasem jednak, czyniąc to, mieszali w nieodpowiednim zestawieniu rzeczy boskie z ludzkimi". ${ }^{17}$ Bacon poteppiał takie starania, twierdząc, że „,z niedorzecznego pomieszania rzeczy boskich i ludzkich wyprowadza się nie tylko fantastyczna filozofię, lecz także heretycką religię. Toteż bardzo zbawienną jest rzeczą, jeżeli kierując się trzeźwym umysłem oddajemy wierze tylko to, co do wiary należy". ${ }^{18}$

Bacon mówił też o innych „idolach”, które przeszkadzały ludziom poprawnie pojmować świat: idolach ,jaskini” i „rynku”. Wydaje się jednak, że dla Bacona to głównie idole teatru i plemienia odpowiadały za to, że ludzka skłonność do poszukiwania przyczyn celowych rodzi tak duże problemy. ${ }^{19}$ Co dokładnie doprowadziło więc Bacona do przekonania, że wnioskowanie o teleologii w przyrodzie wpływa szkodliwie na naukę? Dlaczego przyczyny celowe zaliczał on do dziedziny metafizyki? Dlaczego nie chciał włączać ich, obok przyczyn materialnych i sprawczych, do praktyki eksperymentalnej w fizyce (jak ją nazywał)?

Na szczególną uwagę zasługują dwie ważne negatywne konsekwencje, które według Bacona związane są $\mathrm{z}$ wnioskowaniami teleologicznymi w filozofii przyrody. Po pierwsze, stosowanie takich wnioskowań opóźnia postęp badań, ewaluację i dokonywanie odkryć w filozofii przyrody:

Przyczyny celowe [były] źle umiejscowione [...] To powodowało ułomność lub przynajmniej niesprawność nauk przyrodniczych. Albowiem zajmowanie się przyczynami celowymi, obok innych przyczyn w badaniach fizycznych, udaremniało poważne, skrupulatne badania wszystkich rzeczywistych i fizycznych przyczyn oraz dawało ludziom sposobność do zatrzymywania się na tych zadowalających, lecz bałamutnych przyczynach, co wstrzymywało proces dokonywania dalszych odkryć i wprowadzało doń uprzedzenia. ${ }^{20}$

\footnotetext{
${ }^{17}$ BACON, Novum Organum..., 1:89, s. 118 [wyróżnienia dodane].

${ }^{18}$ BACON, Novum Organum..., 1:65, s. 85.

${ }^{19}$ Por. Richard Kennington, On Modern Origins: Essays in Early Modern Philosophy, Lexington Books, Lanham, Maryland 2004.

${ }^{20}$ Francis BACon, The Two Books of the Proficience and Advancement of Learning, 4th ed., Parker, Son, and Bourn, London 1863, s. 94.
} 
W innym miejscu Bacon stawiał zarzut, że przyczyny celowe są jedynie „przeszkodami i zawadami, które zatrzymują i roztrzaskują statek, uniemożliwiając mu dalszą żeglugę; tym samym sprawiały, że zaniedbywano i pomijano milczeniem poszukiwanie przyczyn fizycznych". ${ }^{21}$ Wskazane tu powody bardzo przypominają te podane przez współczesnego filozofa nauki, Roberta Pennocka, w obronie naturalizmu metodologicznego: „Gdyby raz dopuszczono takie nadnaturalistyczne wyjaśnienie [...] wszystkie badania empiryczne mogłyby ustać, ponieważ naukowcy dysponowaliby gotową odpowiedzią na wszystko". ${ }^{22}$

Drugą szkodliwą konsekwencją, której obawiał się Bacon, było to, że zbyt bujna wyobraźnia człowieka we wnioskowaniu o przyczynach celowych doprowadzi nas do fałszywego obrazu rzeczywistości. Jak wspomniałem wyżej, Bacon był przekonany, że ludzie błędnie dostrzegają więcej celowego porządku, podobieństw i związków w przyrodzie niż rzeczywiście istnieje: „rozum ludzki wymyśla [...] paralele, odpowiedniości i stosunki, które w rzeczywistości nie istnieją". ${ }^{23}$ Bacon poszedł nieco dalej, twierdząc, że teleologiczny sposób myślenia $\mathrm{w}$ filozofii przyrody przenosi na przyrodę cechy czysto ludzkie, a skutkiem tego rażąco przeinacza rzeczywistość:

to bowiem, co najbardziej ogólne w przyrodzie, powinno być po prostu stwierdzone tak, jak się je znajduje - istotnie też nie można tu podać przyczyn; mimo to rozum ludzki, który nie umie się zatrzymać, ciągle jeszcze domaga się czegoś bardziej znanego. [...] mianowicie [...] przyczyn celowych, które niewątpliwie odpowiadają raczej naturze człowieka niż naturze wszechświata; one to, pochodząc z tego źródła, w szczególny sposób zepsuły filozofię. ${ }^{24}$

Podsumowując, wydaje się, że tok rozumowania Bacona przebiegał następująco. Człowiek ma skłonność do antropocentrycznego nakładania własnego typu teleologii na przyrodę. Człowiek i Bóg mają całkowicie odmienne sposoby i zdolności myślenia. Ten pierwszy musi zatem zachowywać szczególną ostrożność, aby uniknąć błędnego odczytania przyrody, które może być skutkiem jego własnych zwyczajów i procesów rozumowania. Jednym z bardzo praktycznych

\footnotetext{
${ }^{21}$ BACON, The Two Books..., s. 94.

${ }^{22}$ Robert T. Pennock, Tower of Babel: The Evidence Against the New Creationism, A Bradford Book, MIT Press, Cambridge, Massachusetts 1999, s. 292.

${ }^{23}$ B ACON, Novum Organum..., 1:45, s. 69.

${ }^{24}$ BACON, Novum Organum..., 1:48, s. 71-72.
} 
sposobów na to jest wykluczenie przyczyn celowych z wyjaśnień stosowanych w naukach fizycznych.

Czy Bacon, wysuwając swoją szeroko zakrojoną propozycję nowej i udoskonalonej metody naukowej, wykluczył przyczyny celowe z nauk eksperymentalnych zasadnie, czy też popełnił błąd? Czy spojrzenie z perspektywy czasu może pomóc ujawnić niedostatki jego poglądu, który przyniósł niepożądane konsekwencje dla prawidłowego pojmowania świata przyrody? Czy doświadczenie naukowe zdobyte w czasach po Baconie wskazuje, jak można rozsądnie skorygować jego metodologiczną decyzję wykluczenia teleologii z fizyki?

\subsection{Odpowiedź na poglądy Bacona dotyczące teleologii}

Część współczesnych filozofów i naukowców może wyrażać uznanie dla Francisa Bacona (i nawet mu przyklaskiwać), gdyż wykluczając przyczyny celowe $\mathrm{z}$ fizyki, zasiał on ziarno naturalizmu metodologicznego. Jednak podejście Bacona do teleologii w nauce ma liczne wady, a ci, którzy rozumują dzisiaj podobnie do niego, również mogą się mylić.

Po pierwsze, należy pamiętać, że jednym z powodów, które doprowadziły Bacona do wyeliminowania przyczyn celowych z fizyki, była jego silna antypatia do tego, co uważał on za greckie quasi-panteistyczne pojmowanie przyczyn celowych jako istniejących w rzeczach fizycznych na mocy samej przyrody. W pewnym sensie wydaje się, że Bacon pomstował na wybitnych filozofów greckich nie dlatego, że powoływali się na teleologię jako taką, lecz ze względu na konkretną odmianę teleologii, jaką według niego propagowali. Bacon pisał w De Augmentis:

[Arystoteles i Platon] nieustannie wpajali im [przyczyny celowe]. Większa wina leży tutaj jednak po stronie Arystotelesa niźli Platona. Pozbywając się Boga, źródła przyczyn celowych, zastąpił go przyrodą i otrzymał przyczyny celowe dzięki swojemu przywiązaniu do logiki, nie zaś do teologii [...] Arystoteles, zapładniając przyrodę przyczynami celowymi i uznając, że niczego nie robi ona na próżno, nie potrzebował już Boga. Przyroda zawsze osiąga swoje cele, o ile tylko nic nie stanie jej na przeszkodzie. ${ }^{25}$

\footnotetext{
${ }^{25}$ Francis BACon, De Augmentis Scientiarum Volume I, M. Jones Paternoster-Row, London 1815 , s. 112-113.
} 
W powyższym fragmencie Bacon wskazywał, że tym, co niepokoiło go w greckiej teleologii, było wrażenie, że Arystoteles zignorował nadnaturalne źródło przyczyn celowych (chrześcijańskiego Boga, w którego wierzył Bacon) i zastępując je przyrodą, przypisał jej częściom składowym i prawom — lub samej Naturze w sensie ogólnym — na poły panteistyczną intencjonalność.

Pierwszy błąd popełniony przez Bacona w kwestii teleologii mógł kryć się w sposobie, w jaki odpowiedział on na Arystotelesowską ideę przyczyn celowych. Bacon był rozczarowany zarówno metodą, jak i wynikami Arystotelesowskiej wizji filozofii przyrody, która według niego przeładowana była przyczynami celowymi ugruntowanymi w naturze niezależnej od Boga. Zapewne zbyt pochopnie lub zbyt ogólnie rozumował więc, że wszystkie wnioskowania teleologiczne opierające się na wynikach obserwacji przyrody - czy to prowadzone przez Greków, czy przez kogoś innego - były bezpodstawnie narzucane przez tendencyjne filozoficzne presupozycje. Zdaniem Bacona teleologii nie da się zatem zasadnie wywnioskować w ramach jego odmiany stopniowej, opartej na danych, eksperymentalnej, empirycznej, indukcyjnej metodologii. Sam Bacon jest prawdopodobnie winny tego, że wylał teleologiczne dziecko ze starożytną kąpielą.

Drugi problem z Baconem polega na tym, że wyrażał on poglądy na teleologię, które - po wnikliwym przemyśleniu — okazują się trudne do pogodzenia ze sobą. Pomimo odrzucenia przyczyn celowych w fizyce, Bacon nadal stanowczo stwierdzał prawomocność i użyteczność wnioskowań teleologicznych bądź w metafizyce, bądź na bardziej abstrakcyjnym poziomie. Według niego Bóg w jakiś sposób kierował przyrodą za pomocą własnych przyczyn celowych.

Jednym z dokuczliwych problemów dotyczących pism Bacona jest to, że nawet pomimo utrzymywania na ogół światopoglądu chrześcijańskiego, nie wyraził on dość jasno swoich przekonań na temat tego, jak kierownicza teleologia Boga przejawia się w świecie fizycznym w sposób, który byłby wykrywalny. Na przykład w sprawie zestawienia przyczyn fizycznych i celowych Bacon pouczał:

Trzymając się swoich kręgów i granic, ludzie ogromnie się łudzą, jeśli sądzą, że istnieje między nimi jakakolwiek wrogość lub niezgodność [...] Obie przyczyny [sa] [...] prawdziwe i zgodne, jedna wskazuje na intencję, druga tylko na konsekwencję. Żadna 
nie przeczy lub nie umniejsza Bożej Opatrzności, lecz wysoce ją potwierdza i wywyższa. ${ }^{26}$

Stwierdził on również:

Tymczasem jeżeli trafnie rzecz ocenić, filozofia naturalna jest po słowie Bożym najpewniejszym lekarstwem przeciw przesądom, a zarazem najbardziej wypróbowanym pokarmem wiary. Dlatego przydziela się ją religii jako najwierniejszą służebnicę, ponieważ jedna objawia wolę Boga, druga - jego potęgę. ${ }^{27}$

Kłopotliwe pytanie brzmi, jak Bacon uzasadnia swoje stanowcze twierdzenia, że filozofia przyrody „deklaruje”, ,potwierdza”, „wywyższa” czy „wykazuje" cokolwiek w kwestii Boga, skoro teleologia nie jest wykrywalna (lub przynajmniej dopuszczona do rozważań) w dziedzinie nauk fizycznych?

W latach dwudziestych dwudziestego wieku filozof Charlie Dunbar Broad podsumował poglądy Bacona następująco:

Bacon utrzymywał, że istnienie teleologii w przyrodzie to oczywisty fakt i że badanie przyczyn celowych stanowi w pełni prawomocną gałąź filozofii przyrody. Teleologię umieszczono jednak w niewłaściwej dziedzinie, należy ona bowiem do działu filozofii przyrody, który Bacon nazywał metafizyką, a nie do działu nazywanego przez niego fizyką [...] [Uważał on], że sztuka fizyki stosowanej nie ma odpowiednika w postaci teleologii stosowanej. Bacon utrzymywał mimo to, że istnienie i pewne atrybuty Boga można ponad wszelką wątpliwość ustalić dzięki refleksji nad teleologią przyrody. ${ }^{28}$

Problematycznym pytaniem pozostaje jednak to, jak można ponad wszelką wątpliwość ustalić istnienie i atrybuty Boga dzięki refleksji nad teleologią przyrody, skoro teleologia została wykluczona z kategorii przyczyn eksplanacyjnych dostępnych w naukach fizycznych? Albo fizyczna natura Wszechświata rzeczywiście mówi nam coś o teleologii, albo nie. Trudno nie mieć odczucia, że Bacon lub jego interpretatorzy usiłują bronić obu możliwości naraz. Podsumowując, nieustępliwie wygłaszane przez Bacona twierdzenia, że filozofia przyrody w jakiś sposób wykazuje i potwierdza przyczyny celowe Stwórcy, najwyraźniej tra-

\footnotetext{
${ }^{26}$ Bacon, The Two Books..., s. 95.

${ }^{27}$ BACON, Novum Organum..., 1:89, s. 119-120.

${ }^{28}$ Charlie Dunbar BROAD, The Philosophy of Francis Bacon: An Address Delivered at Cambridge on the Occasion of the Bacon Tercentenary 5 October 1926, Cambridge University Press, Cambridge, Massachusetts 1926, http://www.ditext.com/broad/bacon.html (04.12.2017).
} 
cą poparcie, gdy releguje on teleologię do dziedziny metafizyki i wyklucza ją z fizyki.

Trzeci problem ze stanowiskiem Bacona polega na tym, że nie dostarczył on świadectw na poparcie swoich wielokrotnie powtarzanych twierdzeń, że teleologiczny sposób myślenia w filozofii przyrody fałszywie przenosi na przyrodę cechy ludzkie. Dlaczego, pomimo ludzkiej skłonności do uprzedzeń, same nauki fizyczne nie mogą zapewnić prawomocnych świadectw empirycznych, które mogłyby nas przekonać, że to, co wydaje się nieodpartą wskazówką zachodzenia przyczynowości celowej, jest rzeczywiste, a nie tylko iluzoryczne? Czy Bacon miał zbyt pesymistyczną wizję mankamentów ludzkiej skłonności do dostrzegania wzorców, porządku i analogii w przyrodzie?

Blisko związany z nieuzasadnionym poglądem Bacona na rozum ludzki jest inny nieuzasadniony pogląd na Boga, o którym była mowa nieco wyżej. W swoich pismach Bacon nie przedstawia jasno konkretnych powodów, dla których ma pewność, że Boskie i ludzkie metody, schematy i zdolności myślenia należą do nieporównywalnie odmiennych dziedzin. Według niego między tymi dwoma rodzajami metod, schematów i zdolności po prostu istnieje zasadniczo niemożliwa do zasypania przepaść, ale nie wydaje się, by Bacon szczegółowo wyjaśnił, dlaczego taki pogląd utrzymywał. Kennington komentuje, że dla Bacona „przyczyna celowa to antropomorfizm [...] Naturalnym dążeniem ludzkiego rozumu nie jest wiedza, lecz zapewnienie lub gwarancja, że wszystko, co istnieje, ma jakiś cel lub służy czemuś dobremu. W rezultacie przyrównywane jest to do religii lub dążenia do życzliwej i pojmowalnej siły boskiej”. ${ }^{29}$ Jeśli Kennington ma rację, to Bacon sądził, że ten antropomorfizm jest złudzeniem (a może urojeniem?). Stąd, jak się zdaje, można wyciągnąć wniosek, że złudzeniem jest także to, że życzliwy i pojmowalny Bóg rządzący domniemaną teleologią jest wysoce analogiczny do nas, ludzi. Jeżeli Bacon w to wierzył — a zgodnie z jedną tez niniejszego artykułu tak właśnie było - to nie wydaje się, aby wyjaśnił on, dlaczego w to wierzył. Jeśli jest to wyłącznie jego założenie, to ma ono decydujące znaczenie dla zagadnienia naturalizmu metodologicznego i prawomocności wnioskowań teleologicznych w nauce.

Istnieje także czwarty problem z poglądami Bacona. Wyżej wskazałem, że Bacon krytycznie patrzył na tendencję w filozofii przyrody polegającą na po-

\footnotetext{
${ }^{29}$ Kennington, On Modern Origins..., s. 21.
} 
chopnym przeskakiwaniu od skąpych danych eksperymentalnych do szerokich uogólnień. W zamian zalecał on wysoce indukcyjną metodę naukową, która „wyprowadza twierdzenia ogólne ze zmysłów i twierdzeń szczegółowych, posuwając się nieprzerwanie i stopniowo wzwyż, aby na końcu dojść do tego, co najbardziej ogólne". ${ }^{30}$ Bacon nigdzie nie uzasadnia, dlaczego metoda pilnego, nieustannego, stopniowego, gruntownego posuwania się wzwyż od empirycznych obserwacji przyrody (za którą się opowiada) nie doprowadzi, lub nawet w zasadzie nie może doprowadzić, naukowców do ogólnych wyjaśnień (czy aksjomatów), które mówią o teleologii.

Piąty problem (za który, jako że żył w wieku siedemnastym, nie należy go winić) związany jest $\mathrm{z}$ tym, że twierdzenia Bacona, iż w odniesieniu do nauk fizycznych wnioskowania teleologiczne są aroganckie, obstrukcyjne, umieszczone w niewłaściwej dziedzinie lub bałamutne, wydają się coraz bardziej niezgodne z odkryciami naukowymi dokonywanymi w późniejszych czasach, a zwłaszcza z najnowszymi głównymi trendami. Po części wygląda na to, że Bacon krytykował panującą od dawien dawna filozofię przyrody, ponieważ od czasów starożytnych Greków zgromadzono znacznie większą wiedzę empiryczną, która unieważniła wiele tradycyjnych poglądów na temat rzeczywistego funkcjonowania świata. Z odrobiną poczucia wyższości Bacon zauważył: „Ciasna bowiem i ograniczona była w owej epoce [czyli epoce słynnych starożytnych filozofów greckich] znajomość czasu i świata; a jest to okoliczność bardzo szkodliwa, zwłaszcza dla tych, którzy ze wszystkim zdają się na doświadczenie. [...] W naszych zaś czasach [...] niezmiernie też powiększył się zasób doświadczeń". ${ }^{31}$

Od czasu ogłoszenia prac Bacona, w których zaproponował on nową metodę naukową, minęło blisko pięćset lat. W tym okresie zasób doświadczeń oraz wiedza o świecie przyrody powiększyły się co najmniej tak bardzo, jak wówczas, gdy pisał o tym Bacon. Przez pięćset lat wiedza naukowa nagromadziła się dzięki procesowi indukcyjnemu (wysoce doświadczalnemu), który zapewne spotkałby się $\mathrm{z}$ aprobatą Bacona. Jak pokażę w następnej części, odkrycia te przyniosły empiryczne świadectwa przyczyn pośrednich (zapożyczam tę terminologię od Kenningtona), które w coraz większym stopniu uwiarygodniają obecność przyczyn celowych.

\footnotetext{
${ }^{30}$ BACON, Novum Organum..., 1:19, s. 61.

${ }^{31}$ BACON, Novum Organum..., 1:72, s. 96.
} 
Wiele, a może nawet wszystkie wymienione tu problemy dałoby się rozwiązać, gdyby Bacon dysponował jeszcze dwoma rzeczami: po pierwsze, pełniejszym zrozumieniem mocy i prawomocności analogii jako narzędzia rozumowania, i po drugie, pięcioma dodatkowymi stuleciami wysoce rozszerzonych i pogłębionych badań nad organizmami biologicznymi oraz odpowiadającymi im zdumiewajacymi osiagnięciami w dziedzinie zaprojektowanych przez człowieka urządzeń i systemów technicznych. Wiele tych osiągnięć zarówno w nauce, jak i w technice, przekonująco wskazuje, że dzięki rozważnemu posługiwaniu się analogia między tymi dwoma dziedzinami - na przykład analogia między narządami a ludzkimi urządzeniami i na odwrót - można w sposób zasadny wyprowadzić indukcyjnie wniosek o istnieniu teleologii w zjawiskach przyrodniczych. Co więcej, te same zjawiska, w tym zwłaszcza biologiczne narządy, organizmy, układy i ich oddziaływania, można znacznie dokładniej i całościowo (a więc lepiej) zrozumieć. Zanim przyjrzymy się zagadnieniu analogii bliżej, warto krótko poruszyć tematy teleologii wewnętrznej i zewnętrznej oraz ich znaczenia dla wnioskowań z analogii w odniesieniu do przyrody, ponieważ gdyby Bacon to rozważył, mógłby dojść do wniosku, że nie należy wykluczać teleologii z procesu rozumowania w fizyce.

\section{Związek między teleologią wewnętrzną i zewnętrzną a analogią}

Pewni badacze, w tym także ja, zgadzają się, że Bacon popełnił poważny błąd, wykluczając przyczyny celowe (to jest teleologię) z nauki. Każdy z nas zgodziłby się, że byłoby dobrze, gdyby nauka powróciła do tego, co wydaje się oczywiste dla wielu uważnych obserwatorów przyrody, czyli do uznania, że teleologia stanowi rzeczywisty składnik wielu układów naturalnych i organizmów. Mimo to niektórzy z tych uczonych niewątpliwie nie zgodziliby się z moim twierdzeniem, że analogia między narządami a artefaktami jest prawomocnym narzędziem umożliwiającym lepsze zrozumienie świata biologicznego. Na przykład Edward Feser i Alexander Sich przyjmują sztywne rozróżnienie na teleologię wewnętrzną i teleologię zewnętrzną. Twierdzą oni, że teleologia w obiektach przyrodniczych lub organizmach ma charakter wewnętrzny, i sprzeciwiają się wykorzystywaniu artefaktualnego, zewnętrznego modelu do jej wyjaśniania. 
Odrzucają próby wzorowania naszej wiedzy o układach naturalnych i organizmach (lub narządach) na artefaktach zaprojektowanych przez człowieka. ${ }^{32}$

Po głębszym zastanowieniu ścisłe rozróżnienie na wewnętrzną i zewnętrzną teleologię, przyjmowane przez Fesera i Sicha, może stać się znacznie mnie wyraźne niż się twierdzi. Utrzymując, z jednej strony, że przyczyny w naturalnych (nieświadomych) składnikach (na przykład w organizmach biologicznych) mają „wbudowaną” lub „przyrodzoną” ${ }^{33}$ teleologię, Feser podkreśla także, że każdą teleologią kierować musi jakiś „,intelekt”. ${ }^{34}$ Skoro nieświadomość i kierujący intelekt nie mogą istnieć jednocześnie $\mathrm{w}$ tym samym bycie, wynika $\mathrm{z}$ tego, że w większości wypadków teleologia w przyrodzie wymaga ostatecznie zewnętrznego intelektu, nawet wówczas, gdy tymczasowo lub „pośrednio” taka teleologia ma charakter wewnętrzny.

Tomasz z Akwinu jasno przedstawia tę mieszankę ostatecznie zewnętrznej i pośrednio wewnętrznej teleologii w swojej słynnej Piątej Drodze za pomocą analogii do wystrzelenia strzały w kierunku celu przez łucznika. ${ }^{35}$ Gdy strzała opuszcza łuk, bezpośrednia teleologia łucznika przenosi się na strzałę. „Zasada ruchu i zmiany" przekształca się z zewnętrznej (mającej źródło w łuczniku) w wewnętrzną (czyli w strzale). Czy zatem przyczyny celowe są w większej części przyrody wewnętrzne czy zewnętrzne? Odpowiedź, jak się zdaje, zależy od tego, na którym etapie całego procesu zamierzamy się skupić.

\footnotetext{
${ }^{32}$ Por. Edward Feser, „Nature versus Art”, Edward Feser Blog 30 April 2011, http://edward feser.blogspot.com/2011/04/nature-versus-art.html (06.12.2017); Alexander SicH, „The Independence and Proper Roles of Metaphysics in Support of an Integrated Understanding of God's Creation", w: Jonathan Bartlett, Dominic Halsmer, and Mark Hall (eds.), Engineering and the UItimate: An Interdisciplinary Investigation of Order and Design in Nature and Craft, Blyth Institute Press, Broken Arrow, Oklahoma 2014, s. 39-62.

Sich przyjmuje to rozróżnienie po części dlatego, że dostrzega poważną słabość w przywoływaniu analogii do maszyn w celu zrozumienia organelli biologicznych. Według niego takie rozumowanie wywodzi się z nieprawomocnego odwrócenia „niezwykle ważnej zasady Arystotelesa: sztuka (artefakt) imituje przyrodę".

${ }^{33}$ Por. FesER, ,Nature versus Art...”.

${ }^{34}$ Por. Edward FesEr, The Last Superstition: A Refutation of the New Atheism, St. Augustine's Press, South Bend, Indiana 2008, s. 115-116.

${ }^{35}$ Por. Tomasz z Akwinu, Suma teologiczna, przeł. Pius Bełch, t. 1, Veritas, London 1975, cz. I, zag. 2, art. 3 .
} 
Rozróżnienie na wewnętrzną i zewnętrzną teleologię zamazuje się również, gdy odwołujemy się do procesów darwinowskich w celu wyjaśnienia różnorodności biologicznej. Biologowie ewolucyjni często przywołują „koopcję” jako proces ewolucyjny, który był przyczyną powstania wysoce złożonych narządów lub układów. Jednak w procesie darwinowskiej koopcji „,eechy, które wyewoluowały w jednym zespole warunków, zostały przejęte [drogą mutacji i doboru naturalnego, z których ten ostatni jest zewnętrzny względem organizmu], by pełnić inną funkcję w innym zespole warunków". ${ }^{36} \mathrm{Jak}$ więc można stanowczo twierdzić, że nowa funkcja - przynajmniej częściowo wytworzona z zewnątrz jest „wbudowana”, „przyrodzona” lub „immanentna”? Czy cały proces ewolucji - czyli domniemane bogactwo funkcjonalnych zmian w czasie ogółem - nie mógłby być postrzegany, przynajmniej po części, jako ogromny zespół zewnętrznych teleologicznych przekształceń?

Zwolennik teorii inteligentnego projektu, William Dembski, również uważa, że rozróżnienie na wewnętrzną i zewnętrzną teleologię, wyrażone w Arystotelesowym odróżnieniu obiektów naturalnych i artefaktów, ,jest siłą rzeczy dość nieostre". Dembski sugeruje, że najnowsze odkrycia naukowe mogą wskazywać na „zewnętrzny projekt” (to jest na ostatecznie zewnętrzne źródło tego, co obecnie postrzegamy tylko jako teleologię wewnętrzną, którą Dembski najwyraźniej utożsamia z informacją) przejawiający się w układach ożywionych. ${ }^{37}$

Jeżeli granica między teleologią wewnętrzną a zewnętrzną okazuje się nieostra, to przepaść związana $\mathrm{z}$ analogią między artefaktami a obiektami naturalnymi wydaje się kurczyć. Co więcej, wygląda na to, że gdy podejmujemy próby pełniejszego i dokładniejszego zrozumienia organelli biologicznych, stosowanie analogii między nimi a urządzeniami lub systemami zbudowanymi przez człowieka zyskuje jeszcze większe uzasadnienie.

\subsection{Artefakty a obiekty naturalne}

Czy Bacon, dzięki stosowaniu analogii między obiektami naturalnymi a ludzkimi artefaktami, mógłby zasadnie utrzymać teleologię w dziedzinie fizy-

\footnotetext{
${ }^{36}$ Deborah A. McLennan, „The Concept of Co-option: Why Evolution Often Looks Miraculous", Evolution, Education, and Outreach 2008, vol. 1, no. 3, s. 247 [247-258].

${ }^{37}$ Por. William A. Dembsкi, Being as Communion: A Metaphysics of Information, Ashgate Publishing, Burlington, Vermont 2014, s. 55.
} 
ki i czy takie podejście jest możliwe, a nawet wskazane, w dzisiejszej nauce? Jak wspomniałem wyżej, uczeni, tacy jak Feser i Sich, stanowczo odrzuciliby taką metodologię. Według nich istnieje wyraźne rozróżnienie między obiektami naturalnymi a artefaktami, a tych ostatnich nigdy nie należy przywoływać przypuszczalnie nawet na mocy analogii — jako środków opisu tych pierwszych.

Sich twierdzi, że „biologia bada naturalne układy ożywione”, i następnie wyjaśnia, że termin „naturalny” ma zastosowanie do tych rzeczy, w przypadku których przyczyny celowe (czy też ,zasady ruchu lub zmiany”) mają charakter wewnętrzny. Artefakty, przeciwnie, to te rzeczy, w przypadku których przyczyny celowe są zewnętrzne, i dlatego nie należą one do zakresu biologii. ${ }^{38}$ Sich kładzie nacisk na „niezwykle ważną zasadę Arystotelesa: sztuka (artefakt) imituje przyrodę, a nie na odwrót". Następnie ostrzega, że liczni naukowcy i myśliciele, w tym zwolennicy teorii inteligentnego projektu, którzy twierdzą, że to „przyroda imituje sztukę (artefakt)”, popełniają „błąd redukcjonizmu «mechanistycznego»". ${ }^{39}$ Sich konkluduje, że porównywanie komórek żywych lub ich części do „fabryk” i „maszyn” to przykład „mętnego myślenia, które stawia rzeczywistość na głowie". ${ }^{40}$

To, czy jakiś zwolennik teorii inteligentnego projektu twierdził kiedykolwiek, że przyroda imituje artefakt, nie jest takie oczywiste. ${ }^{41}$ Poglądy teoretyków projektu często zdają się sugerować jedynie, że pewne struktury czy układy naturalne oraz pewne artefakty wydają się analogiczne. Analogia nie odpowiada na pytanie, czy któryś z analogów wywodzi się z drugiego. Nie wygląda więc na to, by sposób rozumowania teoretyków projektu groził odwróceniem zdroworozsądkowego dictum Arystotelesa.

\footnotetext{
${ }^{38}$ Por. Sich, „The Independence and Proper Roles of Metaphysics...”.

${ }^{39}$ Sich, „The Independence and Proper Roles of Metaphysics...”, s. 53.

${ }^{40}$ SICH, „The Independence and Proper Roles of Metaphysics...”, s. 54.

${ }^{41}$ William Dembski utrzymuje że, ,teoria inteligentnego projektu ma na celu odkrywanie mocnych świadectw naukowych na rzecz rzeczywistej teleologii w przyrodzie. Zwykle, w celu zapewnienia takich świadectw, stosuje pewne sformułowanie materialistycznej logiki refutacji. Nie znaczy to jednak, że teoria inteligentnego projektu musi przyjmować mechanistyczny, redukcjonistyczny bądź artefaktualny pogląd na życie lub Wszechświat" (Dembski, Being as Communion..., s. 60).
} 
Kolejny argument przemawiający za prawomocnością stosowania analogii między obiektami naturalnymi a ludzkimi urządzeniami lub systemami dotyczy zakresu przejawiania się teleologii. Feser (najwyraźniej podążając za Arystotelesem i Akwinatą) definiuje przyczyny celowe tak szeroko, że mogą one mieścić się w zakresie od jedynie regularnie obserwowanych, nieświadomych i z pozoru niefunkcjonalnych skutków ${ }^{42}$ po wysoce wyspecyfikowane, złożone, uprzednio zaaranżowane i nastawione na jakiś cel strategie ludzkiego umysłu. Przypuszczalnie ze względu na ten szeroki zakres Feser zdaje się dopuszczać swego rodzaju kontinuum, w ramach którego teleologia w przyrodzie (świecie fizycznym) jest mniej lub bardziej oczywista, mniej lub bardziej wyraźna. Feser mówi, że „ludzki umysł przejawia przyczynowość celową w sposób bardziej oczywisty niż cokolwiek innego [...] Umysł stanowi najoczywistszy paradygmat przyczynowości celowej". ${ }^{43}$

Jeżeli ludzie, a zwłaszcza ludzkie umysły, są najoczywistszym przejawem teleologii w świecie przyrody, to wydawałoby się, że wykorzystywanie ludzkiej teleologii - szczególnie tej, która przejawia się w jej wytworach — do analogicznej analizy teleologii w przyrodzie jest w pełni prawomocne. Chcemy nieustannie zwiększać naszą wiedzę o świecie przyrody. Już całkiem dobrze rozumiemy świat ludzki. Jak będe przekonywać później, analogia stanowi kluczowe narzędzie zdobywania wiedzy, które pomaga nam korzystać z tego, co już dobrze wiemy, aby zrozumieć to, czego jeszcze nie wiemy. Wiele zatem przemawia za wykorzystywaniem bogatych w teleologię ludzkich, artefaktualnych urządzeń i systemów do przeprowadzania (i potencjalnego testowania) wnioskowań $\mathrm{z}$ analogii w odniesieniu do tego, co wygląda na bardzo podobne, bogate $\mathrm{w}$ teleologię cechy świata biologicznego.

${ }^{42} \mathrm{~W}$ związku z uwagą poczynioną wcześniej Feser twierdzi, że arystotelicy nawet nieświadome byty, takie jak asteroidy czy góry, postrzegali jako przejawiające „przyczynowość celowa o tyle, o ile [są one] [...] «nakierowane na» wytworzenie pewnego określonego zakresu skutków" (FESER, The Last Superstition..., s. 238).

${ }^{43}$ Feser, The Last Superstition..., s. 194. Feser sugeruje również istnienie stopniowalnego kontinuum, gdy pisze, że „ludzka myśl i działanie stanowią najoczywistsze przykłady zjawisk przejawiających nieredukowalną teleologię, ale nie są jedynymi. W istocie przyczynowość celowa przenika świat przyrody od poziomu złożonych narządów biologicznych $a \dot{z}$ do najprostszych oddziaływań przyczynowych na poziomie mikroskopowym" (Feser, The Last Superstition..., s. 248 [wyróżnienia dodane]). 
Stephen Talbott wskazuje na dodatkowe potężne problemy empiryczne odnośnie do kwestii prawomocności analogii między artefaktami a organizmami. Talbott prawidłowo wskazuje, że w literaturze naukowej roi się od porównań organelli komórkowych do „maszyn”. ${ }^{44}$ Obszernie ilustruje on jednak, że obraz wyłaniający się z biologii komórkowej nie zgadza się w pełni z mechanistycznym poglądem mówiącym o przyczynowości działającej oddolnie. Twierdzi on, że wyjaśnienie życia jako „nieożywionej maszynerii na poziomie molekularnym było chybione”. ${ }^{45}$ Lepszym ujęciem jest raczej „zunifikowane i nieredukowalne funkcjonowanie komórki i organizmu jako całości - żywa forma podlegająca metamorfozie [...]". ${ }^{46}$ Talbott podsumowuje w najogólniejszych kategoriach, jak należy pojmować organizmy: „wszystko [...] w komórce jest [...] przejawem życia. [...] Jako metafora naukowego pojmowania biologii $[\ldots]$ «jest to życie do samego dołu»". ${ }^{47}$

Zaproponowane przez Talbotta opisy najnowszych odkryć wymagają głębokiego, powtórnego przemyślenia tego, jak najlepiej pojmować i wyjaśniać życie na poziomie komórkowym. Niekoniecznie wykluczają one jednak stosowność lub użyteczność znajdowania analogii między ludzkimi urządzeniami i systemami a życiem organicznym na poziomie komórkowym.

Po pierwsze, podjęta przez Talbotta próba ogólnego podsumowania tego, czego dowiadujemy się o fundamentalnej naturze organizmów, nie wydaje się szczególnie pomocna. Niebezpiecznie zbliża się on do tautologii mówiącej, że „życie jest życiem”. Stosowanie analogii do projektu człowieka przynajmniej pozwala nam dowiedzieć się czegoś nowego. Jedna z mocnych stron analogii leży w jej subtelnym zrównoważeniu podobieństw i różnic. Aby analogia była jak najlepsza, oba analogi muszą być bardzo podobne, ale nie identyczne. Stwierdzenie, że „kruk jest czarny jak kruk”, nie objaśnia zbyt wiele.

\footnotetext{
${ }^{44}$ Por. Stephen Tацвотт, „The Unbearable Wholeness of Beings”, The New Atlantis Fall 2010, s. 28 [27-51], http://www.thenewatlantis.com/docLib/20110328_TNA29Talbott.pdf (07.12. 2017).

${ }^{45}$ Stephen Tацвотт, „Getting Over the Code Delusion”, The New Atlantis Summer 2010, s. 9 [3-27], http://www.thenewatlantis.com/docLib/20100914_TNA28Talbott.pdf (07.12.2017).

${ }^{46}$ Tацвотт, „Getting Over the Code Delusion...”, s. 9.

${ }^{47}$ Tацвотт, „Getting Over the Code Delusion...”, s. 14, 25.
} 
Po drugie, Talbott przytacza $\mathrm{z}$ aprobatą następującą wypowiedź Franka R. Lilliego: „nie jest możliwe, by nieulegający zmianom układ mógł wyjaśnić uporządkowaną ścieżkę rozwojową. Niezmienne rzeczy nie mogą same z siebie wyjaśniać procesów dynamicznych". ${ }^{48}$ Możliwe jest jednak, by za pomocą czegoś, co jest niezmienne, wyjaśniano nie całe procesy dynamiczne, lecz ich części. Analogie do urządzeń wytworzonych przez człowieka nie muszą pomagać nam w zrozumieniu całego systemu życia organicznego, lecz powinny dość dobrze pomagać zrozumieć pewne składniki życia.

Wreszcie, w części, w której Talbott najwyraźniej chce podsumować główne twierdzenie, że „organizm nie jest maszyną”, pisze on: „nie istnieje oczywiste podobieństwo między maszyną do szycia, zegarkiem lub jakąkolwiek inną maszyną a - dajmy na to - skręcającym się, ulegającym ekspresji chromosomem". ${ }^{49} \mathrm{Z}$ jakiegoś powodu Talbott dobrał nazbyt uproszczone i w dużej mierze nieistotne przykłady, które sprawiają, że analogie do ludzkich urządzeń brzmią niewiarygodnie. Tymczasem istnieją przykłady ze świata ludzkich wynalazków i projektów, które są znacznie ciekawsze i przynajmniej nieco bardziej podobne do dynamicznych, interaktywnych zjawisk, dla których Talbott szuka wyjaśnienia.

Niektóre z tych istotniejszych przykładów przedstawię w dalszej części niniejszego artykułu. Wcześniej należy się jednak zapoznać z ogólnym wprowadzeniem do zagadnienia analogii. W następnej części podejmę próbę odpowiedzi na następujące pytania: jakie zasady rządzą rozumowaniem $\mathrm{z}$ analogii i jakie cechy należy przypisać użytecznym, wysoce pouczającym analogiom?

\section{Analogia (czyli indukcyjne wnioskowanie o teleologii)}

\subsection{Teoria analogii: krótkie wprowadzenie}

Mówiąc najogólniej, analogia stanowi jeden z najbardziej podstawowych sposobów, w jakie ludzie uczą się czegoś nowego. Jest to metoda polegająca na wykorzystywaniu zasobu już posiadanej wiedzy w celu lepszego zrozumienia tego, co jeszcze dla nas nieznane. Mówiąc zaś konkretniej, analogia to narzę-

\footnotetext{
${ }^{48}$ Talbott, „Getting Over the Code Delusion...”, s. 8.

${ }^{49}$ Tацвотт, „The Unbearable Wholeness of Beings...”, s. 37.
} 
dzie, które było powszechnie używane i okazało się przydatne zarówno w ogólnie rozumianej nauce, jak i w przypadku hipotez dotyczących powstawania biologicznych innowacji. ${ }^{50}$ Najpierw należy jednak zapytać, jakie standardy rządzą właściwym stosowaniem analogii w hipotezach naukowych, to znaczy takim, aby mogło to sprzyjać rozwojowi nauki i przybliżać dociekania naukowe do prawdy. Co może zachęcić do stosowania wiarygodnych, mocnych analogii oraz unikania analogii powierzchownych i słabych?

Dedre Gentner i Arthur Markman podkreślają, że dzielenie abstrakcyjnych związków (które nazywają oni „wyższym rzędem”) między dwoma analogami jest ważniejsze od innych, konkretniejszych (lub bardziej prozaicznych) podobieństw między nimi: „Pasujący do siebie zespół relacji powiązany relacjami ograniczającymi wyższego rzędu tworzy lepsze analogiczne dopasowanie niż równa liczba pasujących do siebie relacji, które nie są ze sobą powiązane". ${ }^{51}$

Analogia teleologiczna zdaje się spełniać standard pasujących do siebie relacji wyższego rzędu. Wymagana jest relacja przyczynowa między teleologią a wyspecyfikowanymi i złożonymi cechami ludzkich artefaktów. Ta sama relacja przyczynowa wyższego rzędu jest następnie nakładana na wyspecyfikowane i złożone cechy zjawisk przyrodniczych, wskazując na teleologię jako analogiczny czynnik przyczynowy.

Duża ilość pokrywających się cech także może nie mieć znaczenia dla siły analogii: „Teoria oparta jedynie na względnej liczbie wspólnych i odmiennych predykatów nie może zapewniać adekwatnego ujęcia analogii, a więc nie może też stanowić dostatecznej podstawy dla ogólnego ujęcia pokrewieństwa". ${ }^{52}$ C. Kenneth Waters krytykuje uznawanie ,indukcji enumeracyjnych” jako dobrych analogii. Ubolewa on, że taka praktyka:

\footnotetext{
${ }^{50}$ Por. James C. LeMASter, A Critique of the Rejection of Intelligent Design as a Scientific Hypothesis by Elliott Sober From His Book Evidence and Evolution, rozprawa doktorska, Southern Baptist Theological Seminary 2014. Treść części o analogii w tym artykule, za wyjątkiem bezpośrednich lub pośrednich cytatów z innych autorów, została w większości skopiowana lub zaadaptowana $\mathrm{z}$ mojej rozprawy doktorskiej.

${ }^{51}$ Dedre Gentner and Arthur B. Markman, „Structure Mapping in Analogy and Similarity”, American Psychologist 1997, vol. 52, no. 1, s. 47 [45-56].

${ }^{52}$ Dedre Gentner, „Structure Mapping: A Theoretical Framework for Analogy”, Cognitive Science 1983, vol. 7, s. 156 [155-170].
} 
ignoruje te relacje, dzięki którym argumenty mają charakter analogii. Tradycyjne ujęcia nie dostrzegają więc szczególnego schematu rozumowania, który leży u podstaw wnioskowań z analogii. Nie ma się co dziwić, że te tradycyjne ujęcia skłaniały filozofów do wniosku, że argumenty z analogii są zbyt słabe, by uzasadniać hipotezy naukowe. Prowadziły też do umniejszania ich roli jako uzasadnień w całej historii nauki. ${ }^{53}$

Można zadać pytanie, „czy przywołanie przyczyny teleologicznej wymaga dosłownego - a nie tylko analogicznego (w terminologii Gentnera) - podobieństwa między ludzkimi artefaktami a organizmami biologicznymi’? Zwolennicy poglądu, że w przyrodzie istnieje teleologia (na przykład zwolennicy teorii inteligentnego projektu), nie muszą twierdzić, że w fizycznych przejawach dwóch porównywanych zjawisk dostrzegalne jest dosłowne podobieństwo. Jednakże w najważniejszym aspekcie wyspecyfikowana złożoność (cecha wyższego rzędu), artefakty i organizmy są w dosłownym sensie podobne, nawet izomorficzne. Co więcej, fizyczne podobieństwo nie jest konieczne do porównywania pewnych ludzkich artefaktów — na przykład traktora i kopii Hamleta aby móc zasadnie wywnioskować, że oba przejawiają teleologię. Jeśli tylko ktoś chce, może wskazać wszystkie cechy, ze względu na które traktor i Hamlet nie wykazują „dosłownego podobieństwa”, ale oba te artefakty posiadają tę samą ogólną przyczynę wyższego rzędu, mianowicie teleologię.

$\mathrm{Na}$ ogólnym poziomie Keith Holyoak i Paul Thagard twierdzą, że „,analogia stanowi część wnioskowania do spójnych teorii eksplanacyjnych". ${ }^{54}$ Mimo że ostatecznie preferują oni teorię Darwina, ${ }^{55}$ to i tak doceniają przywołaną przez Williama Paleya słynną analogię do zegarmistrza jako argument na rzecz teleologii w przyrodzie. Nazywają ją ,wyrafinowaną analogią opartą na mapowaniu systemowym". ${ }^{56}$ Piszą też, że:

Argument z projektu ewidentnie wykorzystuje mapowanie systemowe, co widoczne jest w [...] relacji ,przyczynowej” wyższego rzędu zarówno w analogu źródłowym

${ }^{53}$ C. Kenneth WATERS, „Taking Analogical Inference Seriously: Darwin's Argument from Artificial Selection", w: PSA: Proceedings of the Biennial Meeting of the Philosophy of Science Association: Volume 1: Contributed Papers, The University of Chicago Press, Chicago 1986, s. 503 [502-513].

${ }^{54}$ Keith J. Holyoak and Paul Thagard, Mental Leaps: Analogy in Creative Thought, MIT Press, Cambridge, Massachusetts 1995, s. 170.

${ }^{55}$ Por. Holyoak and Thagard, Mental Leaps..., s. 174.

${ }^{56}$ Holyoak and Thagard, Mental Leaps..., s. 172. 
(zegarek/zegarmistrz), jak i w analogu docelowym (świat/Bóg). Rzeczywiście istnieje więc wyjaśnienie analogiczne, które sprawia, że hipoteza boskiego aktu stwórczego zasługuje na uwzględnienie $\mathrm{w}$ procedurze wnioskowania do najlepszego wyjaśnienia. ${ }^{57}$

Holyoak i Thagard twierdzą ponadto, że analogie, nawet te zawierające wyraźne izomorfizmy, nie gwarantują doskonałego odzwierciedlenia rzeczywistości. Dochodzą jedynie do wniosku, że wziąwszy pod uwagę izomorfizmy, analogie wyciągane na podstawie źródła „będą miały pewną wiarygodność w odniesieniu do obiektu docelowego". Ponieważ wiarygodność nie jest tym samym, co pewność, więc według nich najlepsze, co można zrobić, to korzystać z analogii tymczasowo, aby „wyprowadzać wnioski dotyczące przedmiotu dociekań, a następnie sprawdzać, czy te wnioski rzeczywiście dają się utrzymać po bezpośrednim jego zbadaniu". ${ }^{58}$ Taka procedura najprawdopodobniej zyskałaby aprobatę Bacona.

\subsection{Problemy dotyczące Hume'owskiej krytyki argumentów $\mathrm{z}$ analogii na rzecz projektu}

W Dialogach o religii naturalnej David Hume omawia analogie używane do wyciągania wniosku o istnieniu teleologii w przyrodzie. ${ }^{59}$ Hume'owska krytyka rozumowań z analogii jest dobrze znana: „Kiedy [...] nieznacznie choćby odejść od podobieństwa przypadków, odpowiednio do tego słabnie i siła dowodu i można w końcu zredukować ją do bardzo tylko słabej analogii, która, jak wiadomo, bywa omylna i zawodna". ${ }^{60}$ Hume sugeruje następnie, że ze względu na uderzający brak podobieństw analogie między ludzkimi artefaktami a zjawiskami przyrodniczymi mogą ostatecznie okazać się nie lepsze niż zwykłe domysły: „Odmienność jest tak jaskrawa, że co się tyczy podobieństwa przyczyny

\footnotetext{
${ }^{57}$ Holyoak and Thagard, Mental Leaps..., s. 174.

${ }^{58}$ Holyoak and Thagard, Mental Leaps..., s. 30.

${ }^{59}$ Por. Dawid Hume, Dialogi o religii naturalnej, w: Dawid Hume, Dialogi o religii naturalnej. Naturalna historia religii wraz z dodatkami, przeł. Anna Hochfeldowa, Biblioteka Klasyków Filozofii, Państwowe Wydawnictwo Naukowe, Warszawa 1962, s. 23 [1-136].

${ }^{60}$ Hume, Dialogi o religii naturalnej..., s. 24 [wyróżnienie w oryginale].
} 
możesz co najwyżej utrzymywać, że je zgadujesz, że się go domyślasz, że takie powziąłeś przypuszczenie". ${ }^{61}$

Rozumowaniu Hume'a można postawić różne zarzuty, ale na szczególną uwagę zasługuje jeden z nich. Gdy Hume wykazywał, że jeśli podobieństwa zmniejszają się, to analogia słabnie, zapomniał wspomnieć, że zachodzi również relacja odwrotna: kiedy dwa analogi stają się coraz bardziej podobne, analogia zyskuje na sile. Od czasów Hume'a minęło ponad dwieście lat, w trakcie których dokonywał się postęp techniki i nauki. Wiele wynalazków i odkryć dało (i zapewne nadal daje coraz większe) podstawy dla znacznie wiarygodniejszych wnioskowań z analogii między ludzkimi artefaktami a przyrodniczymi strukturami lub układami niż te, które Hume krytykował w Dialogach. Na przykład podobieństwa między wyspecyfikowaną złożoną informacją w DNA a tą w językach komputerowych ${ }^{62}$ lub podobieństwa między maszynerią komórkową a mikro-maszynerią zaprojektowaną przez człowieka najprawdopodobniej stanowią znacznie dobitniejszą — dzięki zastosowaniu rozumowania z analogii wskazówkę działania podobnych przyczyn niż Hume (lub Bacon) był w stanie sobie kiedykolwiek wyobrazić.

\subsection{Nauka stosuje analogie regularnie i z powodzeniem}

Naukowcy nierzadko korzystają z analogii jako potężnych narzędzi w procesie rozwoju i analizy wiarygodności swoich hipotez. Albert Einstein i Leopold Infeld pisali:

W fizyce często się zdarzało, że zasadniczy postęp osiągano drogą przeprowadzenia konsekwentnej analogii między pozornie nie związanymi z sobą zjawiskami. [...] wykrywanie ukrytych pod powierzchnią zewnętrznych różnic - zasadniczych cech

\footnotetext{
${ }^{61}$ Hume, Dialogi o religii naturalnej..., s. 25.

${ }^{62}$ Hubert Yockey pisze, że „Należy zrozumieć, że nie stosujemy rozumowania z analogii. Hipoteza sekwencji stosuje się bezpośrednio do białka i tekstu genetycznego, jak również do języka pisanego, i dlatego są one matematycznie identyczne” (Hubert P. YockeY, „Self Organization Origin of Life Scenarios and Information Theory", Journal of Theoretical Biology 1981, vol. 91, no. 1, s. 16 [13-31]). Wbrew twierdzeniu Yockeya, gdy porównywane przez niego układy (funkcjonalne łańcuchy aminokwasów i ludzkie języki) rozpatruje się od strony materialnej, rzeczywiście mogą być one analogiczne, a nie zupełnie identyczne. Kluczowa cecha wyspecyfikowanej złożonej informacji jest jednak odwzorowana między nimi identycznie, co stanowi uzasadnienie dla izomorficznej, teleologicznej analogii między przyczynami obu układów.
} 
wspólnych i budowanie na tej podstawie nowej, płodnej teorii jest ważną, twórczą pracą. ${ }^{63}$

Johannes Kepler podobno nazywał analogie swoimi „najbardziej godnymi zaufania mistrzami”. ${ }^{64}$ Gentner podaje przykłady naukowców, takich jak Newton, Galileusz i Rutherford, którzy stosowali analogie, gdy formułowali swoje teorie. ${ }^{65}$ Henri Poincaré czuł, że analogia jest kluczowym czynnikiem w procesie rozwoju nauki. ${ }^{66}$ Raimo Antilla, profesor lingwistyki w UCLA, twierdzi, że „,analogie są niezbędnymi składnikami wszystkich teorii [...] [Analogia] jest szczególnie wartościowa, gdy przedmiot badań nie jest bezpośrednio obserwowalny". ${ }^{67}$ Holyoak i Thagard prezentują długą listę analogii, które okazały się nadzwyczaj płodne w rozwoju nauki. ${ }^{68}$ Inni dostrzegli kluczową rolę analogii w tworzeniu i weryfikowaniu hipotez naukowych. ${ }^{69}$

Holyoak i Thagard ostrzegają jednak, że analogia „często może prowadzić do fałszywych wniosków". ${ }^{70}$ Sugerują więc, że analogię powinno się stosować na etapach odkrywania i rozwijania typowego procesu naukowego, lecz nie należy się do nich uciekać w procesie ewaluacji. Mimo to zauważają oni, że pewni powszechnie szanowani naukowcy nie postępowali zgodnie z ich kryterium.

\footnotetext{
${ }^{63}$ Albert Einstein i Leopold Infeld, Ewolucja fizyki. Rozwój poglądów od najdawniejszych pojęć do teorii względności i kwantów, przeł. Ryszard Gajewski, Państwowe Wydawnictwo Naukowe, Warszawa 1962, s. 239-240.

${ }^{64}$ Por. George Polya, Mathematics and Plausible Reasoning: Volume 1: Induction and Analogy in Mathematics, Princeton University Press, Princeton, New Jersey 1954, s. 12.

${ }^{65}$ Por. Dedre Gentner, „Are Scientific Analogies Metaphors?”, w: David S. Miall (ed.), Metaphors: Problems and Perspectives, Humanities Press, Atlantic Highlands, New Jersey 1982, s. 106-132; Hume, Dialogi o religii naturalnej...; Thomas C. Chamberlin, „The Method of Multiple Working Hypotheses”, Science. New Series 1965, vol. 148, no. 3671, s. 754-759.

${ }^{66}$ Por. Henri PoINCARÉ, Wartość nauki, przeł. Ludwik Silberstein, Nakład Jakoba Mortkowicza, G. Centnerszwer i Ska, Warszawa 1908.

${ }^{67}$ Raimo Antilla, Trends in Linguistics: State-of-the-Art Reports: Volume 10: Analogy, Mouton Publishers, The Hague 1977, s. 17.

${ }^{68}$ Por. Holyoak and Thagard, Mental Leaps..., s. 186-187.

${ }^{69}$ Por. Joost M. Woltering, „From Lizard to Snake: Behind the Evolution of an Extreme Body Plan", Current Genomics 2012, vol. 13, no. 4, s. 289-299; Helmar Gust, Ulf Krummack, Kai-Uwe Kühnnerger, and Angela Schwering, „Analogical Reasoning: A Core of Cognition”, Künstliche Intelligenz 2008, vol. 22, no. 1, s. 8-12.

${ }^{70}$ Holyoak and Thagard, Mental Leaps..., s. 190.
} 
Szczególną uwagę poświęcają Karolowi Darwinowi, który „otwarcie uznał analogię między doborem naturalnym a doborem sztucznym jako jedną z podstaw dla wiary w jego teorię". ${ }^{71}$

\subsection{Przekonujące wspólczesne przykłady analogii teleologicznych}

Postępy w dziedzinie zwanej biologią syntetyczną dają okazję do znalezienia coraz większej ilości analogów stanowiących podstawę dla indukcyjnego argumentu teleologicznego. Biologowie molekularni i syntetyczni poczynili już imponujące kroki w kierunku wytworzenia mikroskopijnego życia w laboratorium. Na szczególną uwagę zasługują dwie cechy eksperymentów przeprowadzanych $\mathrm{w}$ ramach biologii syntetycznej. Po pierwsze, cechy powstających w ich wyniku wytworów coraz bardziej przypominaja cechy żywych bakterii. Po drugie, czynnikiem dogłębnie przenikającym te eksperymenty i ich wytwory jest intencjonalny, inteligentny projekt. To, co pionierzy syntetycznego życia, Craig Venter i jego współpracownicy, robili przez ostatnie kilkadziesiąt lat, stanowi ucieleśnienie zjawiska teleologicznego. ${ }^{72}$

Chemik Fazale Rana przedstawia zarys trzech ogólnych stadiów - przy czym wszystkie przeniknięte są inteligencją i teleologicznym zamysłem w projekcie zsyntetyzowania życia podjętym przez zespół Ventera: a) przygotowanie się do syntezy genomu; b) zsyntetyzowanie genomu i c) transplantacja genomu. Co ciekawe, niedawno zakończony przełomowy projekt zespołu Vente$\mathrm{ra}^{73}$ najprawdopodobniej wymagał również czwartego stadium - w równym stopniu przejawiającego teleologię. Chodzi mianowicie o minimalizację genomu.

Każde stadium tego projektu niezbędnie wymaga aspektów celowych, takich jak intensywne planowanie, duża dbałość o szczegóły, pełna współpraca, krytyczne uwagi i konsultacje, ocena i uczenie się na błędach, kreatywność, dobrze rozwinięta umiejętność rozumowania oraz doświadczenie - wszystko to

\footnotetext{
${ }^{71}$ Holyoak and Thagard, Mental Leaps..., s. 190.

${ }^{72}$ To śmiałe przedsięwzięcie ma co najmniej dwa ostateczne cele: 1) stworzyć w laboratorium życie, które potencjalnie może przynieść korzyści ludzkości; 2) przynieść furę pieniędzy.

${ }^{73}$ Por. Andy Coghlan, „Artificial Cell Designed in Lab Reveals Genes Essential to Life”, New Scientist 24 March 2016, http://tiny.pl/glvpn (09.12.2017).
} 
dla zrealizowania jasno określonego celu. Krótko mówiąc, teleologia jest niezbędnym składnikiem tego procesu od jego początku do końca.

Poza bezpośrednim udziałem zespołu Ventera jego sukces, jak dotąd, wymagał też ściśle kontrolowanych warunków laboratoryjnych oraz specjalistycznej aparatury, która sama została wyprodukowana przez inne, kierujące się teleologią ludzkie korporacje. Co więcej, zespół Ventera wspierał się osiągnięciami pokoleń wcześniejszych badaczy, których sukcesy również wymagały zaplecza o teleologicznym charakterze. ${ }^{74}$ Fazale Rana podsumowuje, że Venter i jego współpracownicy

polegali na osiągnięciach wcześniejszych naukowców. Technika chemicznego syntetyzowania oligonukleotydów stanowi zdumiewające osiągnięcie techniczne będące rezultatem ponad pięćdziesięciu lat gorliwych wysiłków najlepszych naukowców na świecie (w tym laureatów Nagrody Nobla). Bez tych błyskotliwych umysłów i niezwykłych osiągnięć zespół Ventera nie mógłby żywić nadziei na przeprowadzenie pełnej syntezy genomu M. genitalium. ${ }^{75}$

Podsumowując, inteligentny i intencjonalny proces wytworzył funkcjonalny genom, izomorficznie analogiczny do niezliczonej ilości innych genomów, które obserwujemy w świecie przyrody. Produkt lub skutek jest zasadniczo identyczny $\mathrm{z}$ dwoma analogami. Wiemy, że powstanie jednego z tych skutków (syntetycznego genomu) od początku do końca wymaga intensywnych teleologicznych wysiłków i procesów. Poprawne rozumowanie z analogii, za punkt wyjścia biorące obserwowane zjawiska (kierowane teleologią działania zespołu tworzącego syntetyczne życie), daje indukcyjną podstawę dla racjonalnego wyjaśnienia tego, jak powstały analogiczne skutki (całe mnóstwo obserwowanych genomów naturalnych).

Innym przykładem organelli stanowiącej podstawę indukcyjnego argumentu teleologicznego jest syntaza ATP. Ten układ wewnątrzkomórkowy przejawia wysoce izomorficzną analogię do turbinowego generatora hydroelektrycznego.

${ }^{74}$ Na przykład Andrew Murray i Jack Szostak komentują, że „dostępność inżynierii genetycznej umożliwia [...] budowanie sztucznych chromosomów ze sklonowanych odcinków DNA" (Andrew W. Murray and Jack W. Szostak, „Construction of Artificial Chromosomes in Yeast”, Nature 1983, vol. 305, no. 5931, s. 189-193).

${ }^{75}$ Fazale Rana, Creating Life in the Lab: How New Discoveries in Synthetic Biology Make a Case for the Creator, Baker Books, Grand Rapids 2011, s. 46. 
Na przykład, jeśli chodzi o zintegrowaną funkcjonalność w obu analogach, to wspólne działanie ruchu obrotowego, dwóch silników, centralnego wału napędowego, statora i kilku innych podjednostek ${ }^{76}$ przekształca energię potencjalną w energię mechaniczną i wreszcie w przenośną formę energii (generator wytwarza energię elektryczną, a syntaza ATP produkuje cząsteczkę ATP).

Zważywszy na cechy syntazy ATP, wielu biologów molekularnych przyrównało ją do urządzeń zaprojektowanych przez człowieka. Według zespołu Christopha von Ballmoosa „syntaza F1F0 ATP to miniaturowy silnik składający się $\mathrm{z}$ dwóch przeciwległych motorów obrotowych”. ${ }^{77}$ Steven Block pisze, że „gdy krystaliczna struktura F1ATPazy została ostatecznie ustalona, wyglądała ona zupełnie jak trójtłokowy motor obrotowy, złożony z sześciokątnego pierścienia par $\alpha-\beta$ otaczającego wał napędowy utworzony z podjednostki $\gamma \cdot{ }^{78}$ Co ciekawe, zespół Roberta Nakamoto ${ }^{79}$ wskazuje, że analogia do ludzkich motorów mogła odegrać kluczową rolę w zrozumieniu syntazy ATP: „Centralna lokalizacja podjednostki c i jej ewidentne podobieństwo do wału rozrządu zainspirowały badaczy do konstruowania ujęć nastawionych na wykazanie zachodzenia rotacji”. ${ }^{80}$

Ponadto, pomimo braku fizycznego podobieństwa, niektóre najnowsze wytworzone przez człowieka urządzenia lub systemy (albo ich zespoły) mają (lub najprawdopodobniej niedługo będą miały) przynajmniej część cech, których brak skłonił Stephena Talbotta do odrzucenia analogii między organellami a maszynami. Takie cechy mogą obejmować oddziaływania między przyczynowo-

\footnotetext{
${ }^{76}$ Por. Robert K. NaKamoto, Joanne A. Baylis Scanlon, and Marwan K. Al-Shawi, „The Rotary Mechanism of the ATP Synthase", Archives of Biochemistry and Biophysics 2008, vol. 476, no. 1, s. 43-50; Steven M. BLock, „Real Engines of Creation”, Nature 1997, vol. 386, no. 6622, s. 217-219; Holger Seelert, Ansgar Poetsch, Norbert A. Dencher, Andreas Engel, Henning Stahlberg, and Daniel J. Mülller, „Proton-Powered Turbine of a Plant Motor”, Nature 2000, vol. 405 , no. 6785 , s. $418-419$.

${ }^{77}$ Christoph von Ballmoos, Alexander Wiedenmann, and Peter Dimroth, „Essentials for ATP Synthesis By F1F0 ATP Synthases”, The Annual Review of Biochemistry 2009, vol. 78, s. 655 [649-672].

${ }^{78}$ B Lock, ,Real Engines of Creation...”.

${ }^{79}$ Por. Nakamoto, Scanlon, and Al-Shawi, „The Rotary Mechanism of the ATP Synthase...”.

${ }^{80}$ Marco Piccolino, na Rysunku 3 swojego artykułu o maszynach molekularnych, umieszcza nawet obok siebie ilustracje koła wodnego i syntazy ATP (por. Marco PIccolino, „Biological Machines: From Mills to Molecules”, Nature Reviews Molecular Cell Biology 2000, vol. 1, no. 2, s. 149-153).
} 
ścią odgórną i oddolną, wrażliwość i przystosowanie do bezpośredniego środowiska fizycznego, kierowaną środowiskiem spontaniczną regulację, a także odległe, celowe interakcje. Przykładami urządzeń lub systemów mających przynajmniej część tych cech są sonda Cassini (której pierwotną misję dwukrotnie przedłużono), systemy autopilota w samolotach, inteligentne bomby, smartfony, system Siri firmy Apple, systemy nawigacji GPS i samochody z asystentami parkowania, które - miejmy nadzieję - dadzą początek bezpiecznym, autonomicznym samochodom wyposażonym $\mathrm{w}$,,radarowy system kontroli jazdy, sensory ruchu, systemy ostrzegające przed zmianą pasa jezdni, system stabilizacji toru jazdy i system satelitarnego mapowania cyfrowego". ${ }^{81}$

Takie przykłady najprawdopodobniej zapewniłyby Baconowi narzędzia potrzebne do przedstawienia świadectw empirycznych wiodących do wyjaśnienia jakiegoś ważnego zjawiska przyrodniczego i jednocześnie wspierających jego twierdzenie, że filozofia przyrody potwierdza i sławi prawdę o przyczynach celowych (mających, według Bacona, źródło w Bożej Opatrzności ${ }^{82}$ ).

\section{Zakończenie}

Z perspektywy ludzi żyjących w dwudziestym pierwszym wieku wydaje się, że Francis Bacon zapędził się w ślepą uliczkę. Z jednej strony można zrozumieć jego wniosek, że Arystotelesowska idea wewnętrznych przyczyn celowych mogła się mocno przyczynić do długotrwałej stagnacji nauki. Można też docenić jego sympatię do systemu kładącego duży nacisk na indukcję drogą stopniowych i gruntownych obserwacji przyczyn i skutków oraz dotyczących ich eksperymentów. Wydaje się jednak, że Bacon posunął się za daleko, stanowczo wykluczając cała teleologię z dziedziny fizyki. Postawiło go to przed problemem, ponieważ bez odwoływania się do teleologii, którą możemy wykryć na podstawie obserwacji przyrody, jego chrześcijańskie przekonanie, że mimo to filozofia przyrody sławi, potwierdza i przejawia to, co uznawał on za źródło teleologii

\footnotetext{
${ }^{81}$ Por. Jet Propulsion Laboratory, „About the Mission: Cassini Mission to Saturn”, 2016, https://saturn.jpl.nasa.gov/mission/about-the-mission/summary/ (10.12.2017); The Automotive eZine, „The GPS Self-Driving Car”, 2016, http://automotive.lilithezine.com/Self-Driving-Car. $\mathrm{html}(10.12 .2017)$

${ }^{82}$ Por. BAcon, The Two Books..., s. 95.
} 
(Boga), wygląda wyłącznie na niczym nie poparty dogmat, który należy przyjąć tylko na podstawie słów jakiegoś religijnego autorytetu.

Gdyby Bacon żył w dzisiejszych czasach, można by mu poradzić, aby przyjął inną postawę: utrzymał swoją empiryczną, indukcyjną metodę, ale niekoniecznie zakazywał wyjaśnień teleologicznych w dziedzinie fizyki, o ile wnioskowania indukcyjne wychodzące od obecnego zasobu obserwacji empirycznych zapewniają takim wyjaśnieniom uzasadnienie. Racją na rzecz takiego podejścia jest fakt, że od początku siedemnastego wieku nauka bez przerwy gromadziła świadectwa (dane empiryczne zebrane w wielu gałęziach nauki), na podstawie których często możemy w sposób indukcyjny formułować wyjaśnienia teleologiczne, stanowiące zapewne najlepsze wythumaczenie obserwowanych zjawisk. Bacon mógłby zapytać, jak mielibyśmy to zrobić? Jak w praktyce można połączyć jego empiryczną metodę indukcji z powoływaniem się na przyczyny teleologiczne, gdy jest to uzasadnione? Otóż dzięki analogii. Posługujmy się analogią jako przyjaciółką indukcji.

James C. LeMaster

\section{Bibliografia}

Antilla Raimo, Trends in Linguistics: State-of-the-Art Reports: Volume 10: Analogy, Mouton Publishers, The Hague 1977.

Bacon Francis, De Augmentis Scientiarum Volume I, M. Jones Paternoster-Row, London 1815.

BACON Francis, De dignitate et augmentis scientiarum, w: RoBertson (ed.), The Philosophical Works of Francis Bacon..., s. 413-638.

BACON Franciszek, Novum Organum, przeł. Jan Wikarjak, Biblioteka Klasyków Filozofii, Państwowe Wydawnictwo Naukowe, Warszawa 1955.

BACON Francis, The Two Books of the Proficience and Advancement of Learning, 4th ed., Parker, Son, and Bourn, London 1863.

Bartlett Jonathan, Halsmer Dominic, and Hall Mark (eds.), Engineering and the Ultimate: An Interdisciplinary Investigation of Order and Design in Nature and Craft, Blyth Institute Press, Broken Arrow, Oklahoma 2014.

BLock Steven M., „Real Engines of Creation”, Nature 1997, vol. 386, no. 6622, s. 217-219. 
Broad Charlie Dunbar, The Philosophy of Francis Bacon: An Address Delivered at Cambridge on the Occasion of the Bacon Tercentenary 5 October 1926, Cambridge University Press, Cambridge, Massachusetts 1926, http://www.ditext.com/broad/bacon. html (04.12.2017).

Chamberlin Thomas C., „The Method of Multiple Working Hypotheses”, Science. New Series 1965 , vol. 148 , no. 3671, s. 754-759.

Coghlan Andy, „Artificial Cell Designed in Lab Reveals Genes Essential to Life”, New Scientist 24 March 2016, http://tiny.pl/glvpn (09.12.2017).

Dembski William A., Being as Communion: A Metaphysics of Information, Ashgate Publishing, Burlington, Vermont 2014.

Dembsk William A. and Ruse Michael (eds.), Debating Design: From Darwin to DNA, Cambridge University Press, Cambridge 2004.

EINSTEIN Albert i INFELD Leopold, Ewolucja fizyki. Rozwój poglądów od najdawniejszych pojęć do teorii względności i kwantów, przeł. Ryszard Gajewski, Państwowe Wydawnictwo Naukowe, Warszawa 1962.

FeSER Edward, „Nature versus Art”, Edward Feser Blog 30 April 2011, http://edwardfeser. blogspot.com/2011/04/nature-versus-art.html (06.12.2017).

Feser Edward, The Last Superstition: A Refutation of the New Atheism, St. Augustine's Press, South Bend, Indiana 2008.

Gentner Dedre, „Are Scientific Analogies Metaphors?”, w: Miall (ed.), Metaphors..., s. 106-132.

Gentner Dedre, „Structure Mapping: A Theoretical Framework for Analogy”, Cognitive Science 1983, vol. 7, s. 155-170.

Gentner Dedre and Markman Arthur B., „Structure Mapping in Analogy and Similarity”, American Psychologist 1997, vol. 52, no. 1, s. 45-56.

Gust Helmar, Krummack Ulf, Kühnberger Kai-Uwe, and Schwering Angela, „Analogical Reasoning: A Core of Cognition”, Künstliche Intelligenz 2008, vol. 22, no. 1, s. 8-12.

Holyoak Keith J. and Thagard Paul, Mental Leaps: Analogy in Creative Thought, MIT Press, Cambridge, Massachusetts 1995.

Hume Dawid, Dialogi o religii naturalnej, w: Hume, Dialogi o religii naturalnej. Naturalna historia religii..., s. 1-136.

Hume Dawid, Dialogi o religii naturalnej. Naturalna historia religii wraz z dodatkami, przeł. Anna Hochfeldowa, Biblioteka Klasyków Filozofii, Państwowe Wydawnictwo Naukowe, Warszawa 1962. 
Hunter Cornelius, „What Evolutionists Don’t Understand About Methodological Naturalism", Darwin's God 27 April 2012, http://darwins-god.blogspot.com/2012/04/what-evolu tionists-dont-understand.html (30.11.2017).

Jet Propulsion Laboratory, „About the Mission: Cassini Mission to Saturn”, 2016, https://sa turn.jpl.nasa.gov/mission/about-the-mission/summary/ (10.12.2017).

Kennington Richard, On Modern Origins: Essays in Early Modern Philosophy, Lexington Books, Lanham, Maryland 2004.

LeMaster James C., A Critique of the Rejection of Intelligent Design as a Scientific Hypothesis by Elliott Sober From His Book Evidence and Evolution, rozprawa doktorska, Southern Baptist Theological Seminary 2014.

McLennan Deborah A., „The Concept of Co-option: Why Evolution Often Looks Miraculous", Evolution, Education, and Outreach 2008, vol. 1, no. 3, s. 247-258.

Miall David S. (ed.), Metaphors: Problems and Perspectives, Humanities Press, Atlantic Highlands, New Jersey 1982.

Murray Andrew W. and Szostak Jack W., „Construction of Artificial Chromosomes in Yeast", Nature 1983, vol. 305, no. 5931, s. 189-193.

Nakamoto Robert K., Scanlon Joanne A. Baylis, and Al-Shawi Marwan K., „The Rotary Mechanism of the ATP Synthase", Archives of Biochemistry and Biophysics 2008, vol. 476, no. 1, s. 43-50.

Pennock Robert T., Tower of Babel: The Evidence Against the New Creationism, A Bradford Book, MIT Press, Cambridge, Massachusetts 1999.

Piccolino Marco, „Biological Machines: From Mills to Molecules”, Nature Reviews Molecular Cell Biology 2000, vol. 1, no. 2, s. 149-153.

Poe Harry Lee i Mүтүк Chelsea Rose, „Od metody naukowej do naturalizmu metodologicznego. Ewolucja idei”, przeł. Bartosz Błaszczak, Gerard Dmuch, Ewa Komorowska, Iwona Kumiszcze, Izabela Obłaczyńska, Katarzyna Piłka, Radosław Plato, Marika Poprawska, Dariusz Sagan, Karolina Stencel, Katarzyna Szot i Piotr Wróblewski, Filozoficzne Aspekty Genezy 2011, t. 8, s. 137-151, http://www.nauka-a-religia.uz.zgora.pl/images/FAG/ 2011.t.8/art.09.pdf (30.11.2017).

PoINCARÉ Henri, Wartość nauki, przeł. Ludwik Silberstein, Nakład Jakoba Mortkowicza, G. Centnerszwer i Ska, Warszawa 1908.

Polya George, Mathematics and Plausible Reasoning: Volume 1: Induction and Analogy in Mathematics, Princeton University Press, Princeton, New Jersey 1954.

PSA: Proceedings of the Biennial Meeting of the Philosophy of Science Association: Volume 1: Contributed Papers, The University of Chicago Press, Chicago 1986. 
Rana Fazale, Creating Life in the Lab: How New Discoveries in Synthetic Biology Make a Case for the Creator, Baker Books, Grand Rapids 2011.

Robertson John M. (ed.), The Philosophical Works of Francis Bacon, George Routledge and Sons, London 1905.

Ruse Michael, „The Argument From Design: A Brief History”, w: Dembski and Ruse (eds.), Debating Design..., s. 13-31.

Seelert Holger, Poetsch Ansgar, Dencher Norbert A., Engel Andreas, Stahlberg Henning, and MüllLER Daniel J., „Proton-Powered Turbine of a Plant Motor”, Nature 2000, vol. 405, no. 6785 , s. $418-419$.

Sich Alexander, „The Independence and Proper Roles of Metaphysics in Support of an Integrated Understanding of God's Creation", w: Bartlett, Halsmer, and Hall (eds.), Engineering and the Ultimate..., s. 39-62.

TAlвotт Stephen, „Getting Over the Code Delusion”, The New Atlantis Summer 2010, s. 327, http://www.thenewatlantis.com/docLib/20100914_TNA28Talbott.pdf (07.12.2017).

Tацвотт Stephen, „The Unbearable Wholeness of Beings”, The New Atlantis Fall 2010, s. 27-51, http://www.thenewatlantis.com/docLib/20110328_TNA29Talbott.pdf (07.12.2017).

Tomasz z Akwinu, Suma teologiczna, przeł. Pius Bełch, t. 1, Veritas, London 1975.

The Automotive eZine, „The GPS Self-Driving Car”, 2016, http://automotive.lilithezine. com/Self-Driving-Car.html (10.12.2017).

von Ballmoos Christoph, Wiedenmann Alexander, and Dimroth Peter, „Essentials for ATP Synthesis By F1F0 ATP Synthases", The Annual Review of Biochemistry 2009, vol. 78, s. $649-672$.

Waters C. Kenneth, „Taking Analogical Inference Seriously: Darwin's Argument from Artificial Selection", w: PSA: Proceedings of the Biennial Meeting..., s. 502-513.

Woltering Joost M., „From Lizard to Snake: Behind the Evolution of an Extreme Body Plan", Current Genomics 2012, vol. 13, no. 4, s. 289-299.

Yockey Hubert P., „Self Organization Origin of Life Scenarios and Information Theory”, Journal of Theoretical Biology 1981, vol. 91, no. 1, s. 13-31.

\section{Związek między Baconem, teleologią i analogią a doktryną naturalizmu metodologicznego}

\section{Streszczenie}

Francis Bacon podzielił nauki przyrodnicze na fizykę i metafizykę. Twierdził, że z czterech przyczyn wskazanych przez Arystotelesa tylko przyczyny materialne i sprawcze należą do dziedziny fizyki, a przyczyny celowe, czy też twierdzenia teleologiczne, zaliczyć trzeba do 
dziedziny metafizyki. Bacon sprzeciwiał się włączaniu teleologii do fizyki, ponieważ doświadczenie podpowiadało mu, że twierdzenia teleologiczne zniechęcają do poszukiwania przyczyn sprawczych dla zjawisk przyrodniczych. Relegował on teleologię do metafizyki, a nauka w dużej mierze poszła jego śladem, wykształcając przez kolejne czterysta lat coraz większą awersję do uwzględniania czynników teleologicznych w wyjaśnieniach naukowych. Zdaniem Bacona człowiek, z racji swojej natury, „,wymyśla [...] paralele, odpowiedniości i stosunki, które w rzeczywistości nie istnieją".

Jednak wraz $\mathrm{z}$ rozwojem nauki w zakresie odkrywania przyczyn materialnych i sprawczych, jaki zachodził od czasów Bacona, zaczęły pojawiać się paralele, odpowiedniości i stosunki bardziej zasadne niż zapewne mógłby on sobie wyobrazić. Krótko mówiąc, poszukiwanie przyczyn materialnych i sprawczych $\mathrm{w}$ przyrodzie przyniosło imponujące uzasadnienie również dla wnioskowania o przyczynach celowych. Wnioskowania teleologiczne powinny być dopuszczone w nauce wówczas, gdy uprawomocniają je świadectwa empiryczne.

Narzędzie pozwalające ustalić, czy wnioskowanie teleologiczne jest prawomocne, stanowi analogia. Bacon mógłby pomóc nauce uniknąć stopniowego, lecz i nieuchronnego przejścia w stronę naturalizmu metodologicznego, gdyby położył nacisk na to, jak analogia, zastosowana $\mathrm{w}$ roli narzędzia analitycznego $\mathrm{w}$ procesie indukcji, prowadzi do zasadnych wniosków o istnieniu teleologii w przyrodzie.

Slowa kluczowe: przyczyna celowa, przyczyna sprawcza, metafizyka, nauka, teleologia wewnętrzna, teleologia zewnętrzna, wnioskowanie teleologiczne, rozumowanie z analogii, biologia syntetyczna.

\section{The Relationship of Bacon, Teleology, and Analogy to the Doctrine of Methodological Naturalism}

\section{Summary}

Francis Bacon divided natural science into physics and metaphysics. He claimed that of Aristotle's four causes, only material and efficient causes belong to the realm of physics, and that final causes, or teleological claims, belong to the realm of metaphysics. Bacon objected to including teleology in physics because in his experience teleological claims tended to discourage the search for efficient causes for natural phenomena. Because Bacon relegated teleology to metaphysics science largely followed his lead, evolving over the next four hundred years a growing distaste for including any teleological implications in scientific explanations. Bacon claimed that human nature, "will yet invent parallels and conjugates and relatives, where no such thing is".

Yet, as the material and efficient causal discoveries by science have progressed since Bacon's time, they have in turn revealed more legitimate parallels and conjugates and relatives than perhaps he could have ever imagined. Stated succinctly, the process of exploring material and efficient causes in nature has also given breathtaking justification for also inferring 
final causes as well. As such, inferences to teleology in science should be allowed where they are warranted by the empirical evidence.

The tool for determining whether a teleological inference is warranted is analogy. Bacon could have helped science avoid its gradual but inexorable drift into methodological naturalism if he had emphasized how analogy, used as an analytical tool in the process of induction, legitimately leads to reasonable inferences of teleology in nature.

Keywords: final cause, efficient cause, metaphysics, science, intrinsic teleology, extrinsic teleology, teleological inference, analogical reasoning, synthetic biology. 